\title{
Effect of Tax Planning on Firms Market Performance: Evidence from Listed Firms in Ghana
}

\author{
Seyram Kawor ${ }^{1} \&$ Holy Kwabla Kportorgbi ${ }^{1}$ \\ ${ }^{1}$ Department of Accounting and Finance, University of Cape Coast, Ghana \\ Correspondence: Seyram Kawor, School of Business, University of Cape Coast, PMB Cape Coast, Ghana. Tel: \\ 233-246-54-7009.E-mail:kazookaw@yahoo.com or sirholy09@yahoo.com
}

\author{
Received: December 4, $2013 \quad$ Accepted: January 6, $2014 \quad$ Online Published: February 25, 2014 \\ doi:10.5539/ijef.v6n3p162 URL: http://dx.doi.org/10.5539/ijef.v6n3p162
}

\begin{abstract}
The study sought to ascertain the level of tax planning of firms and to explore the relationship between tax planning and firms' market performance. The study used 22 non-financial companies listed on the Ghana Stock Exchange over a twelve year period from 2000. The longitudinal correlative designed was used. The results indicate that that firms' tendency to engage in intensive tax planning activities reduces when tax authorities maintain low corporate income tax rates. Secondly, tax planning has a neutral influence on firms' performance. This finding challenges the general perception that every cedi of tax savings from tax planning reflect in the pocket of investors. It is concluded that investors must institute systems to ensure tax planning benefits reflect significantly in their pockets.
\end{abstract}

Keywords: Ghana stock exchange, tax planning, market performance, longitudinal correlative design, investors

\section{Introduction}

Over the years and throughout the world, the history of taxation brings out one fact; that taxes are coercive in nature and therefore economic units which are assigned the tax liability never wholly intend to bear the actual tax burden (Commonwealth Association of Tax Administrators (CATA), 2007). Economic units, more specifically, corporate bodies are always adopting ways to minimise, postpone, or avoid entirely, the payment of tax. The attempts by the economic units to reduce, postpone or avoid tax payment can be legal or illegal. The legal means is called tax planning while the illegal means is called tax evasion. The dire consequence of tax evasion makes it an unattractive option for listed companies (Murphy, 2004).

The practice of tax planning dates back to 1947 when learned judge Hand, in the case Commissioner v Newman, held that there is nothing sinister in arranging ones affairs so as to keep taxes as low as possible. Hoffman's (1961) tax planning theory supports this argument. According to Hoffman, it is a necessity for firms to understand the prevailing tax laws and apply the laws in a manner that ensures the firms minimise their tax exposure. Hoffman posits that it makes no economic sense to pay more tax than what the law demands. Scholes and Wolfson's (1992) tax planning framework also underscores the need for corporate bodies to engage in tax planning. According to Scholes and Wolfson, a successful company is the one that is properly attuned to its tax environment.

International governmental organizations, such as CATA (2009), suggest that corporate bodies in Ghana, especially the large entities, engage in complex tax planning activities. Research by civil society groups such as Christian Aid (2008), Action Aid (2011), and Dan Watch (2011), confirm this assertions made by the Domestic Revenue Division. The missing element in the findings is the quantitative expression of the tax planning activities of the firms.

The traditional thinking is that firms that derive maximum benefit from tax planning perform better than those that do not plan their taxes (Murphy, 2007). From the empirical perspective, tax planning is positively associated with firms' performance. For instance, Desai and Hines (2002); Chen, Chen, Chen and Shelvin (2010) reported positive association between tax planning savings and firm performance. The argument is that tax represents cost of doing business, and any action that has the potential of minimising tax cost reflects in higher firm performance. This argument presupposes that tax planning cost and risk does not exceed the savings from the planning. 
Few studies in the UK dispel the traditional relationship between tax planning and firm performance. While admitting that tax planning has a positive association with accounting performance, Desai and Dharmaphala (2007) reported that tax planning has a neutral association with market performance. Indeed Abdul-Wahab (2010) found a negative association between tax planning and firm performance. Kportorgbi (2013) suggested that corporate governance strength plays a mediating factor in the tax planning-firm performance relationship.

A study of the effect of tax planning savings on firms' market performance is crucial for all stakeholders in the emerging security markets such as the Ghana stock Exchange. In fact each possible relationship has a unique implication for the players. For instance, a positive association implies that tax planning produces a win-win situation for both management and shareholders (investors). A negative association connotes that tax planning benefits may not eventually trickle to the pocket of the shareholder. Indeed, a negative association may be an indicative of the existence of agency problem, where management is inclined to pursue tax planning to enhance their own lot rather than advancing the interest of the investor. Where a neutral association is established, it will invoke a follow up study on the possible factors that could influence the relationship either positively or negatively. Secondly, the study is necessary to inform tax planning agents and investors on the dynamics of tax planning

\subsection{Objective of the Study}

The primary objective of this study is to explore the relationship between tax planning savings of firms listed on the Ghana Stock Exchange and firm market performance. The study also seeks to examine the simultaneous influence of other firm specific variables on the tax planning-market performance relationship.

\subsection{Tax Planning Intensity of Firms in Ghana}

Commentators on tax behaviour of firms in Ghana paint a picture that suggests that large firms engage in tax planning activities. For instance CATA (2009) posits that Ghana Revenue Authority lost seventy-four million pounds between 2005 and 2007 to the European Union (EU) in tax revenue as a result of tax avoidance by several multinational companies. Murphy (2004) also reported that firms have complex gamut of arsenals to reduce their tax burden. The reports indicate that the tax avoiding mechanism of firms are largely allowed by the tax laws. There are also indications that the firms take advantage of the loopholes in the tax laws to derive unintended tax benefits. The avenues for tax planning usually revolve around locational reliefs, industry-specific concessions and capital allowance provitions. Others are time variables and entity variables.

Most of the reports are not precise in their estimation of the benefits that firms achieve through tax planning. The lack of precision in measuring tax planning intensity is largely attributed to the insufficient reporting of issues of taxation by firms. Aside the mandatory disclosures to tax authorities, firms are reluctant in disclosing much on tax behaviours. This is due to the perceived thin line that exist between tax planning and tax evasion. Listed companies, however, provide provide adequate information necessary to estimate the tax savings of the firms. This is made possible by virtue of the financial reporting guidelines provided by the security exchange commision.

\section{Review of Related Literature}

This section is subdivided into theoretical review and empirical review. The theoritical review encapsultes the Hoffman's (1961) tax planning theory. Three main empirical studies are reviewed. They are Desai and Hines (2002), Desai and Dharmaphala (2009) and Abdul-Wahab (2010).

\subsection{Hoffman's Tax Planning Theory}

According to Hoffman (1961) tax planning seeks to divert cash, which would ordinarily flow to tax authorities, to the corporate entities. Tax planning activities are desirable to the extent that they reduce taxable income to the barest minimum, without sacrificing accounting income. The theory is premised on the fact that firms tax liability is based on taxable income rather than accounting income. The idea is thus to intensify activities that reduce taxable income but has no indirect relationship on accounting profit. The theory thus recognised a positive association between firm tax planning activity and firm performance.

Hoffman (1961) also recognised the role of tax cost in the tax planning activities. The theory thus provided that the positive association between tax planning and corporate performance is on a basic assumption that tax benefits from the tax planning exceed tax cost. The scope of the Hoffman's tax planning theory does not address the dynamics of tax planning and market performance. As capital markets develop and the separation of ownership and control of corporate bodies become well-spread, the need for a comprehensive tax planning theory is imperative. This need is rather addressed through the empirical perspective than through theoretical perspective (Inger, 2012). 


\subsection{Empirical Review and Development of Hypothesis}

Desai and Hines (2002) provide evidence on firm performance and tax planning behaviour of firms. Again, the study investigates the relationship between tightening of tax systems and market value of firms. The study was based on 850 listed US firms. The study sample was purposively selected to reflect the characteristics desired by the researchers. The study was cross sectional and the data relates to year 2000. Correlative-description design was adopted. Simple regression and t-tests were used to establish the relationships. Desai and Hines established that intensive tax planning is associated with higher firm performance. On the other hand, the study reported that tightening of the tax system is positively associated with higher market performance of firms. The findings of Desai and Hines (2002) are similar to that reported by Chen, Chen and Chen (2010).

Desai and Dharmapala (2007) provided a comprehensive study that incorporates tax planning, corporate governance and firm performance. The study used 4,492 observations on 862 firms over the period 1993 to 2001 . This panel data was drawn from the Compustat and Execucomp databases, merged with data on institutional ownership of firms from the CDA/Spectrum database. Firms' performance is measured using Tobin's q and governance quality is proxied by the level of institutional ownership. Tax planning is measured by inferring the difference between the income reported to capital markets and tax authorities (the book-tax-gap). Two analysis models were adopted - the OLS model and the IV estimation model. The OLS results shows that the average effect of tax planning on corporate performance is not significantly different from zero. In other words, there is no relationship between tax planning and firm performance. The study however reports a positive association between tax planning savings and performance for well-governed firms. Desai and Dharmapala (2007) thus concluded that corporate governance mediates the tax planning-firm performance relationship. The IV estimate shows a higher effect of corporate governance on firm performance.

Abdul-Wahab (2010) provides a result that differs from the findings of Desai and Hines (2002), Desai and Dhamarpala (2009), and Chen, Chen, Chen and Shelvin. Abdul-Wahab's (2010) study sought to establish a relationship between tax planning savings of firms and their value. The study simultaneously investigates the moderating influence of corporate governance. Abdul-Wahab's study employed 240 firms listed on the London stock exchange from 2005 to 2007. Tax planning was proxied by the difference between the effective tax rate of the entities and the applicable statutory tax rates. Self-constructed governance index was constructed using corporate governance mechanisms. Firms' value was represented by the Tobin's Q. The data was analysed using panel regression analysis model. As a check, the OLS model was also used.

The results indicate a negative relationship between firm value and tax planning activities. Abdul-Wahab (2010) explains the relationship with reference to tax planning cost and risk. The study suggested that tax planning cost and risks associated with tax planning have the potential of derailing the benefits that should have accrued to shareholders. The researcher maintains that as tax planning activities increase, the tax costs and risks outweighs the benefits.

Due to the diversity of the relationships found between tax planning and firms' market performance, it is right to develop a null hypothesis as:

\section{$H_{1}$ : There is an association between tax planning and firms' market performance.}

It is unreasonable to suggest that tax planning is the only determinants of firm performance. Baring the existence of multicollinearity between (among) the explanatory variables, sales growth, financial leverage, firm size and age of the firms will be introduced into the regression models. Several studies, including Desai and Hines (2002), Desai and Dharmaphala (2007), Abdul-Wahab (2010) reported positive association between firm performance and sales growth, firm size and financial leverage. It is thus clear to develop the null hypothesis that:

\section{$\mathrm{H}_{2}$ : Firm performance and sales growth and firm size are positively associated.}

Firms' age, according to Desai and Dharmapala (2007) and Abdul-Wahab (2010) has a negative association with market performance of firms. This gives rise to the third null hypothesis that:

H3: Firms age and financial leverage are negatively associated with firms' market performance.

\section{Methodology}

Longitudinal correlative design is adopted for the study. Longitudinal design is essential if the same research entities sampled in a cross section are then re-sampled at different times (Creswell, 2009; De Vaus, 2001). According to the authors, the design helps overcome limitations associated with the "snap shot" approach of cross sectional designs.

The study population comprises all non-financial firms listed on the Ghana stock exchange. As of June 2013, 
twenty-three (23) out of thirty-five (35) firms listed on the Ghana Stock Exchange were non-financial companies. Financial companies are excluded from the population. Previous researchers posit that the financial sector is a highly regulated sector and as such regulations blur the relationship that exist among the variables to be studied (O'Hamon \& Taylor, 2007; Desai \& Dharmapala, 2009; Abdul-Wahab, 2010).

The study uses a panel data for twelve-year period, from 2000 to 2011. Data for the study is collected from the database of the Ghana Stock Exchange. Panel regression model is adopted for data analysis and the Ordinary least square (OLS) been the method of regression.

The regression model is summarized as:

$$
\text { Tobin's } q=\alpha_{i, t}+1(\text { Taxsavings })_{i, t}+2(\text { Sgrowth })_{i, t}+3\left(\text { Fsize }_{i, t}+4(\text { fLev })_{i, t}+5(\text { Age })_{i, t}+e\right.
$$

$\alpha=$ (alpha) shows the constant affecting net profit margin on corporate tax.

Tobin's q (market performance $)=($ market capitalization of entity $) \div($ book value of shareholders fund) .

Tax savings $=$ Statutory tax rate - Effective tax rate.

Statutory tax rate $=$ flat rate as mandated by the Ghana Revenue Authority.

Effective tax rate $=$ Corporate income tax expense/profit before tax.

Sgrowth $($ sales growth $)=($ Previous Sales revenue - Current sales revenue $) \div$ Previous sales revenue

Fsize (firm size $)=$ Natural log of firm's total assets.

fLev (Financial leverage $)=$ Long term debt/shareholders fund.

Age (Age of firms) $=\log$ (the difference between the year of establishment and years of observation).

\section{Results and Discussion}

Figure 1 and Table 1 presents the descriptive statistics for two key variables, namely tax planning of firms and market performance over the twelve year period.

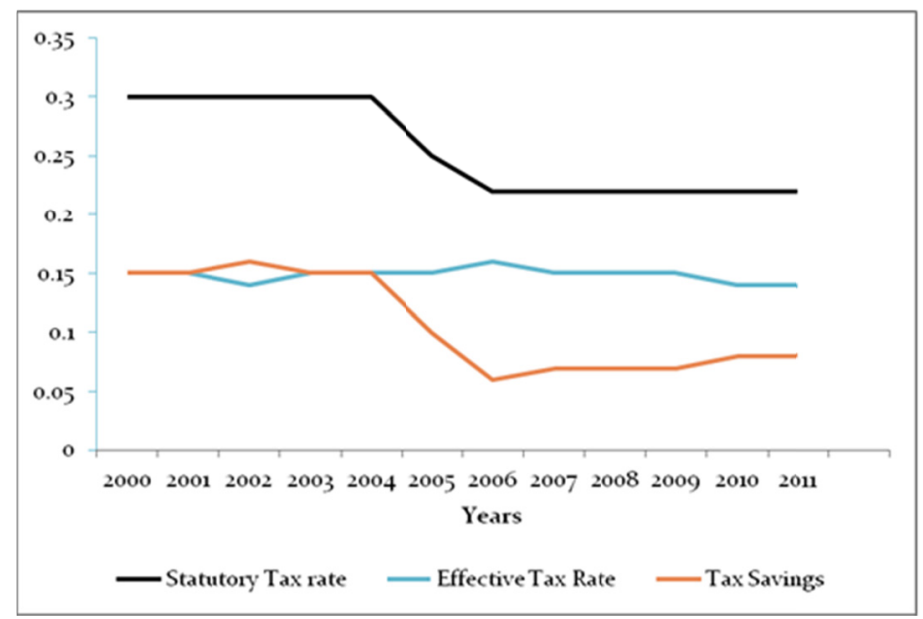

Figure 1. Tax planning of Ghanaian firms

Source: Fieldwork, 2013.

Like the statutory rate, tax savings of firms show a decreasing trend. As tax authorities take steps to reduce the tax burden on firms, the leakages in tax revenue due to firms tax planning activities reduce. From figure 1, the statutory tax rate reduced from about $32 \%$ to $25 \%$. Tax savings of firms reduced also from $15 \%$ to $8 \%$ by 2011 . That is to say each percentage point decrease in the statutory rate leads to a corresponding decrease in firms' tax planning savings.

The policy implication of this finding is two-fold. Firstly, the notion of increasing tax rate in order to rake in more tax revenue may not hold. As tax rates increased, the motivation of firms to deny the state of revenue through intensified tax planning machinery is enhanced. Secondly, as the tax rate is decreased, the net benefit of planning tax is derailed. The way forward for tax revenue optimisation is to maintain lower tax rates and drag more firms into the tax net. 
Table 1 provides the market performance of the firms over the twelve year period.

Table 1. Tobin's Q for the study entities

\begin{tabular}{lccccc}
\hline Industry Classification & Observation & Mean & Median & Std. Deviation & Skewness \\
\hline Service & 26 & 1.38 & 1.21 & 0.53 & 1.13 \\
Oil and Gas & 18 & 1.68 & 1.65 & 0.52 & -0.13 \\
Commerce & 24 & 1.60 & 1.50 & 0.33 & 0.80 \\
Mining & 22 & 2.11 & 2.10 & 0.11 & 0.44 \\
Manufacturing & 131 & 1.70 & 1.80 & 0.47 & -0.40 \\
Total & 221 & 1.69 & 1.78 & 2.8 & -0.81 \\
\hline
\end{tabular}

Source: Fieldwork (2013).

The farther the Tobin's Q is from unity, the better the company performance. From Table 1, all the company groups recorded an average score higher than 1.00. The overall average score is 1.78 (the median represents the average as skewness is negative). The high average market performance by the firms is driven by only the mining sector and the manufacturing companies. All the remaining classes of companies recorded lower than the average score.

This finding confirms the observation of business persons in Ghana that business climate in Ghana gives unmatched advantage to the mining sector. The service sector records the lowest market performance. This raises a major concern as the sector is the major contributor to gross domestic product (GDP) in Ghana. Another sector to watch out for is the oil and gas. This sector has the most recent history. It was expected that the high hopes of investors in the sector after the discovery of oil in commercial quantities in Ghana would have positive influence on the performance. It is expected that the sector will be one of the major drivers of firms' market performance in the future.

Table 2 provides correlation results on the variables. This result is essential for at least two reasons. Firstly, it shows basic association between the dependent variable (market performance) and the independent variable. Secondly, it shows if the "so-called" independent variables are indeed independent. In other words, it tests the multicollinearity status of the independent variables.

Table 2. Pearson's correlation coefficient

\begin{tabular}{|c|c|c|c|c|c|c|c|}
\hline & & Tobin Q & Tax savings & Sales growth & Firm size & Financial Leverage & Age \\
\hline \multirow[t]{2}{*}{ Tobin Q } & Pearson Correlation & 1 & & & & & \\
\hline & Sig. (2-tailed) & & & & & & \\
\hline \multirow[t]{2}{*}{ Tax savings } & Pearson Correlation & .112 & 1 & & & & \\
\hline & Sig. (2-tailed) & .097 & & & & & \\
\hline \multirow[t]{2}{*}{ Sales growth } & Pearson Correlation & .525 & .204 & 1 & & & \\
\hline & Sig. (2-tailed) & .010 & .021 & & & & \\
\hline \multirow[t]{2}{*}{ Firm size } & Pearson Correlation & .433 & .386 & .467 & 1 & & \\
\hline & Sig. (2-tailed) & .021 & .030 & .071 & & & \\
\hline \multirow[t]{2}{*}{ Financial Leverage } & Pearson Correlation & -.633 & -.420 & -.003 & -.018 & 1 & \\
\hline & Sig. (2-tailed) & .001 & .030 & .127 & .016 & & \\
\hline \multirow[t]{2}{*}{ Age } & Pearson Correlation & -.410 & -.485 & -.226 & .088 & -.121 & 1 \\
\hline & Sig. (2-tailed) & .001 & .000 & .001 & .013 & .020 & \\
\hline
\end{tabular}

Source: Fieldwork (2013).

From Table 2, the correlation co-efficient between tax savings and Tobin's Q is 0.112 . This is however significant at 0.097 . This significant level is compared with the default alpha of 0.05 . As rule of thumb, we reject the null hypothesis if the actual significant level is higher than the expected alpha and do not reject if the actual significant is less than the expected alpha. In this instance p-value of 0.097 is greater than the expected alpha of 0.05 . The null hypothesis that:

$\mathrm{H}_{1}$ : There is an association between tax planning and firms' market performance is rejected. 
The correlation results do not suggest causation but gives an indication of association between the variables. The "no relationship" finding between tax planning and firms' market performance supports the reports of Desai and Dharmapala (2007) but differ from the findings of Desai and Hines (2002) and Abdul-Wahab (2010). The findings suggest that although savings from tax planning reflect in higher profit after tax, it does not necessarily reflect in the pocket of shareholders. This finding ignites studies aimed at uncovering factors that mediate the tax planning-firm performance relationship. Indeed, it might be the reasons behind the works of Desai and Dharmapala (2007), Desai and Dharmapala (2009) and Abdul Wahab (2010).

Another finding in table 3 is the relationship between market performance (proxied by tobin's Q) and the firm specific variables. Sales growth and firm size shows positive and significant association with firms' market performance. On the other hand financial leverage and age of the firms shows a negative association with firm performance. The findings

We do not reject the null hypotheses $\left(\mathrm{H}_{2}\right.$ and $\left.\mathrm{H}_{3}\right)$ stated as

$\mathrm{H}_{2}$ : Firm performance and sales growth and firm size are positively associated

$\mathrm{H}_{3}$ : Firms age and financial leverage are negatively associated with firms' market performance.

Further Table 3 gives an indication that multicollinearity among the independent variables does not exist. The rule of thumb is that if the correlation coefficients between any two of the variables is above 0.50 (either positive or negative), those two variables are multi-correlated and should not be simultaneously included in the regression model. From Table 3, this condition does not exist. The variables can be regressed against the dependent variables.

Table 3 shows the regression of Tobin's Q (proxy of firms' market performance) and all the independent variables.

Table 3. Regression analysis: dependent variable: Tobin's Q

\begin{tabular}{lccc}
\hline Variable & Coefficient & P- Value & T-test \\
\cline { 2 - 5 } Constant & 0.283 & 0.003 & 3.042 \\
Financial leverage & -0.419 & 0.025 & -2.263 \\
Firm Size & 0.050 & 0.013 & 2.508 \\
Sales growth & 0.424 & 0.001 & 3.331 \\
Age & -0.056 & 0.699 & -0.388 \\
Tax savings & 0.167 & 0.081 & 2.378 \\
\hline $\mathrm{R}^{2}$ & 0.623 & & \\
Adjusted R & 0.553 & & \\
\hline P-Value & 0.0001 & &
\end{tabular}

Source: Financial statement, 2013.

The adjusted $\mathrm{R}^{2}$ connotes that the five independent variables explain $55.3 \%$ of the variations in the dependent variable. The model is significant at 0.0001 . This is a strong indicator that the variables used in the model have sufficiently explained the firms' market performance.

The regression results found a relationship that is largely consistent with the correlation results shown in table 3 . The results affirm that tax planning plays an insignificant role in the determination of firms' market performance. Again this supports the agency theory's argument that it not all actions of management that help achieve the wealth maximisation objective of management. From the results sales growth and the financial leverage are the two most influential variables. Firms should maintain low financial leverage ratio and pursue sales growth strategies in order to boost their market performance.

\section{Conclusions}

The study sought to ascertain the level of tax planning of firms and to explore the relationship between tax planning and firms' market performance. The study used 22 non-financial companies over a twelve year period from 2000. The longitudinal correlative designed was used. The following conclusions are reached.

Firstly firms' tax savings decrease as tax authorities reduce the statutory corporate income tax rates. This indicates that leakages in tax revenue as a result of intensive tax planning of firms reduce when tax authorities maintain low corporate income tax rates. 
Secondly, tax planning has a neutral influence on firms' performance. This finding challenges the general perception that every cedi of tax savings from tax planning reflect in the pocket of investors. Agency problem is much present in the issue of tax planning. The efforts of management to reduce tax burden of firms benefit other stakeholders rather than shareholders. There may be other factors that could ensure that substantial benefits of tax planning accrue to shareholders. Some researchers arguably, root for good corporate governance. This falls outside the scope of this study.

Finally, sales growth, firm size, age of firms, financial leverage and tax planning simultaneously play a major role in determining firms' market performance. These variables explain $55.3 \%$ of the variations in firms' market performance. Sales growth and financial leverage are the two most influential variables that determine firm market performance.

\section{References}

Abdul-Wahab, N. S. (2010). Tax planning and corporate governance: Effect on shareholders' valuation. Unpublished PhD thesis, University of Southampton, UK. Retrieved from http://eprints.soton.ac.uk

Chen, S., Chen, X., Cheng, Q., \& Shevlin, T. J. (2010). Are family firms more tax aggressive than non-family firms? Journal of Financial Economics, 95(1), 41-61. http://dx.doi.org/10.1016/j.jfineco.2009.02.003

Christian Aid. (2008). Death and taxes: the true toll of tax dodging. Retrieved from http://www.christianaid.org.uk/images/deathandtaxes.pdf

Commonwealth Association of Tax Administrators. (2009). Tax evasion and avoidance: strategies and initiatives used by CATA member countries. UK: Commonwealth Secretariat.

Creswell, J. W. (2009). Research design: qualitative, quantitative, and mixed methods approaches (3rd ed.). Thousand Oaks: Sage Publications.

Dan, W. (2011). Escaping poverty or taxes: A Danwatch investigation of tax planning opportunities in IFC-supported extractives projects in developing countries. Retrieved from http://www.financialtaskforce.org.wp-content/upload/2011

De Vaus, D. (2001). Research design in social research. London: Sage publication.

Desai, M. A., \& Dharmapala, D. (2007). Corporate tax avoidance and firm value. University of Connecticut and University of Michigan, 1-27.

Desai, M. A., \& Dharmapala, D. (2009). Corporate tax avoidance and firm value. The Review of Economics and Statistics, 91(3), 537-546. http://dx.doi.org/10.1162/rest.91.3.537

Desai, M. A., \& Hines, J. R. Jr. (2002). Expectations and expatriations: Tracing the causes and consequences of corporate inversions. National Tax Journal, 55, 409-441.

Hoffman, W. H. (1961). The theory of tax planning. The Accounting Review, 36(2), 274-281.

Inger, K. K. (2012). Relative valuation of alternative methods of tax tax avoidance. Unpublished $\mathrm{PhD}$ thesis, Virginia Polytechnic Institute and State University, Virginia. Retrieved from http://www.papaers.srn.com/sol3/

Kportorgbi, H. (2013). Tax planning corporate governance and performance of listed firms in Ghana. Unpublished Master's thesis. University of Cape Coast. Ghana.

Murphy, K. (2004). Aggressive tax planning: Differentiating those playing the game from those who don't. Journal of Economic Psychology, 25, 307-329. http://dx.doi.org/10.1016/S0167-4870(03)00011-4

O'Halon, J., \& Taylor, P. (2007). The value relevance of disclosures of liabilities of equity-accounted investees: UK evidence. Accounting and business Research, 37(4), 267-284. http://dx.doi.org/10.1080/00014788.2007.9663312

Scholes, M. S., Wilson, G. P., \& Wolfson, M. A. (1992). Firm's responses to anticipated reduction in tax rates: The tax reform act of 1986. Journal of Accounting Research, 3(4), 625-650.

\section{Copyrights}

Copyright for this article is retained by the author(s), with first publication rights granted to the journal.

This is an open-access article distributed under the terms and conditions of the Creative Commons Attribution license (http://creativecommons.org/licenses/by/3.0/). 